\section{Rural Drinking Water Quality Status in Central Development Region, Nepal: A Comparative Study of Spring water and Ground water}

Bishnu Pandey and Suman Shakya

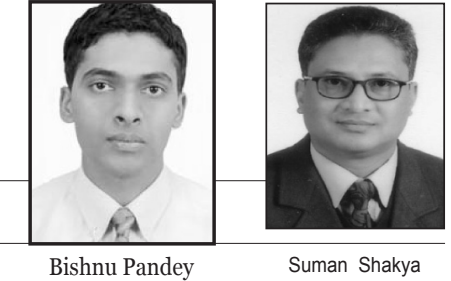

Abstract: This study assesses the rural drinking water quality status in Central Development Region of Nepal. With a total of 250 samples collected from 15 districts of the region, drinking water quality of spring water and ground water representing hill and Terai (lowland) regions were tested and compared for their physicochemical parameters and faecal coliform contamination.

None of the spring samples as well as ground water samples violated National Drinking Water Standards (NDWS) for electrical conductivity (EC), total dissolved solids (TDS), total suspended solids (TSS), appearance, chloride and nitrate. Similarly none violated the standards for total hardness (TH) indicating soft nature of the water. The spring samples were within the NDWS for manganese $(\mathrm{Mn})$ and iron $(\mathrm{Fe})$ whereas $15.4 \%$ and $39.0 \%$ of the ground water samples violated the standards for manganese and iron, respectively. Gravity water is found to be more alkaline than ground water. Faecal coliforms were the most problematic in both types of sources followed by Ammonia (NH3) and $\mathrm{pH}$ in spring sources and by iron, $\mathrm{Mn}, \mathrm{pH}$ and ammonia in ground water sources, respectively. Spring sources were more contaminated by bacteria than ground water sources. Correlation and regression analysis revealed highly significant correlations between EC and TDS $(r=0.979)$ and between $\mathrm{CaH}$ and $\mathrm{TH}(\mathrm{r}=0.988)$ in ground water suggesting that aquifer chemistry of ground water to be mainly controlled by EC, TDS, TH, and CaH. Similarly, highly significant correlations were found between the following pairs in gravity water: EC and TDS ( $r=0.983)$, TA and TDS( $r=0.853)$, $\mathrm{CaH}$ and TDS ( $r=0.912)$, TH and TDS $(r=0.955), \mathrm{EC}$ and $\mathrm{CaH}(r=0.898)$, and between $\mathrm{CaH}$ and TH $(r=0.951)$.

Key words: Rural Drinking Water Quality, Spring water, Ground Water, NDWS (National Drinking Water Standards), Nepal

\section{Introduction}

Still one billion people do not have clean water, and 2.6 billion lack basic sanitation (WaterAid 2007; UN-Water 2008). Like many developing countries Nepal faces a plethora of problem regarding both its drinking water quality and availability (Warner, Levy et al 2008). Faecal contamination of drinking water is the most serious water quality problem in Nepal (ENPHO 2001). Throughout Nepal, people are exposed to severe health threats resulting from water contamination by sewage, agriculture and industry. Owing to the impact of sewage, typhoid, dysentery, and cholera are endemic every summer (Khadka 1993). The diseases are transmitted particularly through human and animal excreta, especially faeces (WHO;UNICEF 2004). Most of the surface waters are heavily loaded with phosphate and nitrate (Merz, Nakarmi et al 2004).

The provision of drinking water supply to the community requires the water to be safe and wholesome. The present study, therefore, attempts to examine the drinking water quality status of the proposed sources of the rural drinking water supply schemes in the project intervention area of the Central Development Region of Nepal. The study has been guided by the following objectives:

- Assess the overall status of physico-chemical and bacteriological water quality of rural drinking water schemes and establish relationship among the water quality parameters.

- To quantify differences in water quality between the spring sources and the ground water sources.

\section{Materials and Methods}

A total of 250 samples was collected during July to September 2009 and subjected to water quality analysis. Out of them, 120 were from springs most of which represent hilly districts (Ramechhap, Sindhuli, Makawanpur, Kathmandu, Lalitpur, Kavre, Sindhupalchowk, Nuwakot, Dhading and Chitwan) and 130 were from tubewells installed ground water sources of lowland Terai districts (Parsa, Bara, Sarlahi, Mahottari and Dhanusa) of Nepal's Central Development Region. Water samples from each source were collected aseptically in sterilized polypropylene bottles (500ml) for physico-chemical analyses and in a sterilized plastic whirl-pack for bacteriological analyses. Ground water samples were collected after allowing the water to flush for sometime operating the hand pumps. Variables such as water temperature, $\mathrm{pH}$ and conductivity were measured in situ. Qualitative and quantitative determinations of faecal coliform bacteria were done following membrane filtration methods (MFM) (APHA 1995).

\section{Results and Discussion \\ Physicochemical parameters}

None of the spring samples nor the ground water samples violated the National Drinking Water Standards (NDWS) (MPPW 2005) for electrical conductivity (EC), total dissolved solids (TDS), total suspended solids (TSS), appearance, chloride $(\mathrm{Cl})$ and nitrate $\left(\mathrm{NO}_{3}\right)$. Similarly none of them violated the standards for total hardness (TH) indicating soft nature of the water. 
Out of 20 ground water samples that violated NDWS for $\mathrm{pH}, 95 \%$ had $\mathrm{pH} 6.5$ and out of 6 gravity samples that violated the standards for $\mathrm{pH}, 86 \%$ had $\mathrm{pH}>8.5$ indicating that spring water is more alkaline than ground water. The spring samples were within the NDWS and the Nepalese standard for manganese (Mn) and iron (Fe). On the contrary, $15.4 \%$ and $39.0 \%$ of the ground water samples violated the standards for $\mathrm{Mn}$ and Iron respectively. Fe concentration reached as high as $5 \mathrm{mg} / \mathrm{L}$ and Mn concentration reached as high as $2.3 \mathrm{mg} / \mathrm{L}$ in ground water samples. Higher concentrations of these elements in deeper sources may be attributed to less aerobic condition.

\section{Bacterial parameters}

Median concentrations of faecal coliform bacteria for ground water and gravity water were 60 colony forming unit (CFU)/100 ml and 105 $(\mathrm{CFU}) / 100 \mathrm{ml}$ respectively being much higher for gravity water sources than ground water sources (Table 2 and Figure 1). Such high proportion of bacterially polluted spring water may be attributed to its unprotected nature. Lacks of protection from surface contamination, lack of protection against silt contamination caused by wind and water erosion and in many cases encroachments by anthropogenic activities such as open defecation and domestic animal activities might be the leading cause for spring source contaminations. Similarly lack of proper drainage system, unsanitary inspection cover at the surrounding due to poor solid waste and sewage management, cracks in the parish and inadequate depth of tubewell installations were the probable cause of bacterial contamination of the ground water.

\section{Correlation and regression analyses}

Table 3 presents the correlation matrix among fourteen water quality parameters of ground water samples showing strong positive correlation between EC and TDS $(r=0.979)$ and between total hardness and calcium hardness $(\mathrm{r}=0.988)$ at $1 \%$ significance level. The regression analyses (Figures 2-4) show good linear positive relationships between these variables suggesting that the aquifer chemistry of the study area is mainly controlled by EC, TDS, TH, and $\mathrm{CaH}$. Similarly the following pairs shows moderate positive correlation at $1 \%$ significance level; EC and $\mathrm{TH}(\mathrm{r}=0.6790), \mathrm{EC}$ and $\mathrm{CaH}(\mathrm{r}=0.686)$, TDS and $\mathrm{TH}(\mathrm{r}=0.650)$, TDS and $\mathrm{CaH}(\mathrm{r}=0.661)$, and iron and $\mathrm{Mn}(\mathrm{r}=0.647)$. Faecal coliform bacteria are found to be positively correlated with $\mathrm{pH}(\mathrm{r}=0.714)$, TDS $(\mathrm{r}=0.315), \mathrm{Cl}(\mathrm{r}=0.364)$, $\mathrm{NO}_{3}(\mathrm{r}=0.29)$ and $\mathrm{NH}_{3}(\mathrm{r}=0.446)$, while nega-

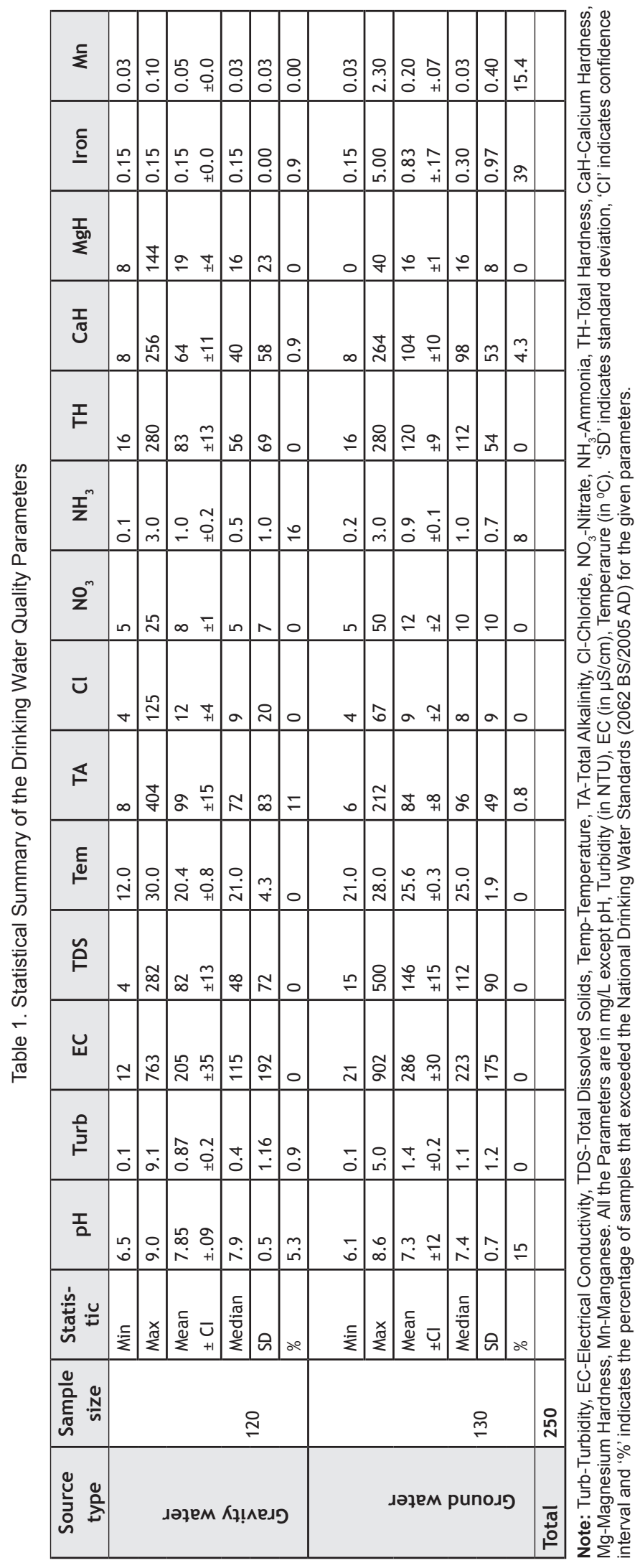


Table 2. Bacterial Contamination in the Two Types of Water Sources

\begin{tabular}{|c|c|c|c|c|c|c|c|}
\hline \multirow{2}{*}{$\begin{array}{c}\text { Source } \\
\text { type }\end{array}$} & \multirow{2}{*}{$\begin{array}{c}\text { No. of } \\
\text { Samples }\end{array}$} & \multicolumn{6}{|c|}{ Faecal Coliform (CFU/100 ml) } \\
\cline { 3 - 8 } & & Min & Max & Mean & Median & IQR & Detected \\
\hline $\begin{array}{c}\text { Ground } \\
\text { water }\end{array}$ & 120 & 0 & 212 & 63 & 60 & $(0,115)$ & $63 \%$ \\
\hline $\begin{array}{c}\text { Gravity } \\
\text { water }\end{array}$ & 130 & 0 & 354 & 110 & 105 & $(62,153)$ & $97 \%$ \\
\hline
\end{tabular}

Note: "Detected" denotes the \% of samples detected $\geq 1$ CFU(Colony Forming Unit)/100 $\mathrm{ml}$ (above the Nepalese drinking water standards), IQR denotes Inter Quartile Range.

tively correlated with Turb $(\mathrm{r}=-0.251)$, TA $(\mathrm{r}=-0.286)$, $\mathrm{MgH}(\mathrm{r}=-0.409)$, iron $(\mathrm{r}=-0.313)$ and $\mathrm{Mn}(\mathrm{r}=-0.26)$.

Similarly, Table 4 represents the correlation matrix among twelve water quality parameters of gravity water samples. EC and TDS showed good positive correlation with major water quality parameters. The correlation between these two parameters was highly significant $(r=0.983)$. Some other highly significant correlations at

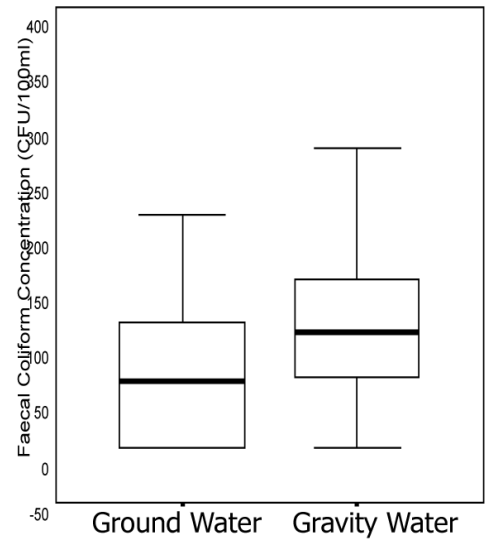

Figure 1. Box Whisker Plot for Bacterial contamination

Table 3. Pearson's Correlation Coefficients Matrix of Hydrochemical Data of Ground Water

\begin{tabular}{|c|c|c|c|c|c|c|c|c|c|c|c|c|c|c|}
\hline & $\mathrm{pH}$ & Turb & EC & TDS & TA & $\mathrm{Cl}$ & $\mathrm{NO}_{3}$ & $\mathrm{NH}_{3}$ & TH & $\mathrm{CaH}$ & $\mathrm{MgH}$ & Iron & $\mathrm{Mn}$ & FC \\
\hline $\mathrm{pH}$ & 1.000 & & & & & & & & & & & & & \\
\hline Turb & $-0.268^{* *}$ & 1.000 & & & & & & & & & & & & \\
\hline TDS & $0.358^{* *}$ & $-0.179^{*}$ & $0.979^{* *}$ & 1.000 & & & & & & & & & & \\
\hline TA & $-0.286^{* *}$ & 0.069 & $0.403^{* *}$ & $0.346^{* *}$ & 1.000 & & & & & & & & & \\
\hline $\mathrm{NH}_{3}$ & $0.380^{* *}$ & $-0.322^{\star *}$ & 0.142 & $0.176^{*}$ & $-0.308^{* *}$ & $0.411^{* *}$ & 0.062 & 1.000 & & & & & & \\
\hline TH & 0.140 & -0.007 & $0.679^{* *}$ & $0.650^{* *}$ & $0.485^{\star *}$ & $0.300^{* *}$ & 0.167 & 0.122 & 1.000 & & & & & \\
\hline $\mathrm{CaH}$ & $0.231^{*}$ & -0.005 & $0.686^{* *}$ & $0.661^{* *}$ & $0.453^{* *}$ & $0.317^{\star *}$ & $0.189^{\star}$ & 0.133 & $0.988^{* *}$ & 1.000 & & & & \\
\hline $\mathrm{MgH}$ & $-0.448^{\star *}$ & -0.016 & 0.027 & -0.006 & $0.261^{* *}$ & -0.073 & -0.124 & -0.123 & $0.184^{*}$ & 0.031 & 1.000 & & & \\
\hline
\end{tabular}

\section{Notes:}

* Correlation is significant at the 0.05 level (2-tailed)

${ }^{* *}$ Correlation is significant at the 0.01 level (2-tailed)

$\mathrm{p}=<0.001$ were found between $\mathrm{EC}$ and TA $(\mathrm{r}=0.850)$, $\mathrm{EC}$ and $\mathrm{TH}(\mathrm{r}=0.949), \mathrm{EC}$ and $\mathrm{CaH}(\mathrm{r}=0.898)$, TDS and TA $(r=0.853)$, TDS and TH $(r=0.955)$, TDS and $\mathrm{CaH}$ $(\mathrm{r}=0.912)$, TA and $\mathrm{TH}(\mathrm{r}=0.806)$, TA and $\mathrm{CaH}(\mathrm{r}=0.750)$ and between $\mathrm{CaH}$ and $\mathrm{TH}(\mathrm{r}=0.951)$ (see Figures 5-10).

\section{Conclusion and Recommendations}

As shown in several previous studies, water in the spring source and ground water sources of Central Development Region, Nepal, is heavily polluted with faecal coliform bacteria. Unlike springs, contamination by iron and manganese was frequently observed in ground water sources. Correlation matrix shows significant relation- ships between the water quality parameters. Regression analysis yields the following relations among the water quality variables for ground water: $\mathrm{EC}=1.96 \mathrm{TDS}+7.78$, $\mathrm{R} 2=0.96$ and $\mathrm{TH}=1.0 \mathrm{CaH}+15, \mathrm{R} 2=0.98$. Similarly, the following relations were obtained for spring water samples: $\mathrm{EC}=2.63 \mathrm{TDS}-10.5, \mathrm{R} 2=0.97, \mathrm{TA}=0.98 \mathrm{TDS}+18.27$, $\mathrm{R} 2=0.73, \quad \mathrm{TH}=1.14 \mathrm{CaH}+9.77, \quad \mathrm{R} 2=0.90$, $\mathrm{TH}=0.92 \mathrm{TDS}+7.24, \quad \mathrm{R} 2=0.91, \quad \mathrm{CaH}=0.73 \mathrm{TDS}+3.8$, $\mathrm{R} 2=0.83$ and $\mathrm{CaH}=2.98 \mathrm{EC}+14, \mathrm{R} 2=0.80$.

Despite its extensive contamination, tubewell installed aquifer and gravity fed piped water as a low cost technology option for drinking water for the rural communities will continue to be relied upon as suitable sources of drinking water. To safeguard the life of these communities, protection of the spring sources from surface 
Table 4. Pearson's Correlation Coefficients Matrix of Hydrochemical Data of Gravity Water

\begin{tabular}{|c|c|c|c|c|c|c|c|c|c|c|c|c|}
\hline & $\mathrm{pH}$ & Turb & EC & TDS & TA & $\mathrm{Cl}$ & $\mathrm{NO}_{3}$ & $\mathrm{NH}_{3}$ & TH & $\mathrm{CaH}$ & $\mathrm{MgH}$ & FC \\
\hline $\mathrm{pH}$ & 1.000 & & & & & & & & & & & \\
\hline Turb & -0.074 & 1.000 & & & & & & & & & & \\
\hline EC & $0.203^{*}$ & 0.017 & 1.000 & & & & & & & & & \\
\hline TDS & 0.157 & 0.073 & $0.983^{\text {** }}$ & 1.000 & & & & & & & & \\
\hline TA & 0.059 & -0.006 & $0.850^{\text {** }}$ & $0.853^{* *}$ & 1.000 & & & & & & & \\
\hline $\mathrm{Cl}$ & 0.022 & 0.150 & -0.044 & -0.048 & -0.097 & 1.000 & & & & & & \\
\hline $\mathrm{NO}_{3}$ & 0.101 & -0.070 & -0.123 & -0.127 & 0.028 & -0.014 & 1.000 & & & & & \\
\hline $\mathrm{NH}_{3}$ & 0.031 & $0.200^{*}$ & $0.209^{*}$ & $0.196^{*}$ & $0.321^{* *}$ & $0.517^{* *}$ & 0.067 & 1.000 & & & & \\
\hline TH & 0.164 & 0.024 & $0.949^{* *}$ & $0.955^{\star *}$ & $0.806^{* *}$ & -0.122 & -0.127 & 0.120 & 1.000 & & & \\
\hline $\mathrm{CaH}$ & 0.090 & 0.032 & $0.898^{* *}$ & $0.912^{* *}$ & $0.750^{* *}$ & -0.146 & -0.117 & 0.068 & $0.951^{* *}$ & 1.000 & & \\
\hline $\mathrm{MgH}$ & $0.270^{* *}$ & -0.009 & $0.602^{* *}$ & $0.581^{* *}$ & $0.542^{* *}$ & 0.001 & -0.088 & $0.191^{*}$ & $0.620^{* *}$ & $0.347^{* *}$ & 1.000 & \\
\hline FC & -0.158 & 0.161 & 0.161 & 0.183 & 0.057 & -0.067 & -0.153 & 0.015 & $0.226^{*}$ & $0.249^{* *}$ & 0.055 & 1.000 \\
\hline
\end{tabular}

Notes:

* Correlation is significant at the 0.05 level (2-tailed)

${ }^{* *}$ Correlation is significant at the 0.01 level (2-tailed)

Fe and $\mathrm{Mn}$ are not included in the matrix of gravity water due to most of their concentrations reaching below the lower detection limit.

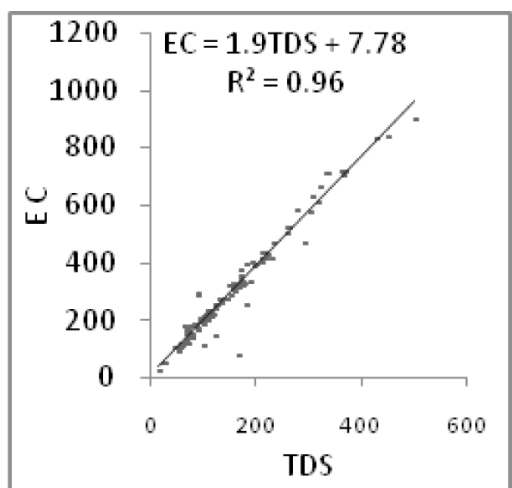

Figure 2. Correlation between EC and TDS

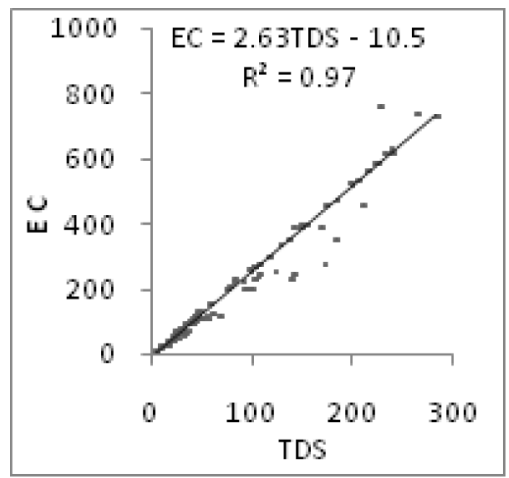

Figure 5. Correlation between EC and TDS

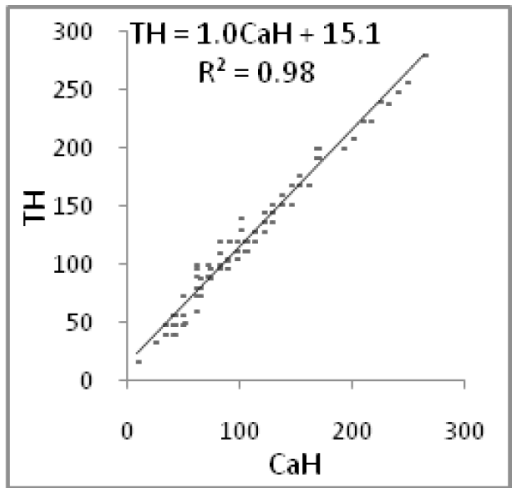

Figure 3. Correlation between TH and $\mathrm{CaH}$

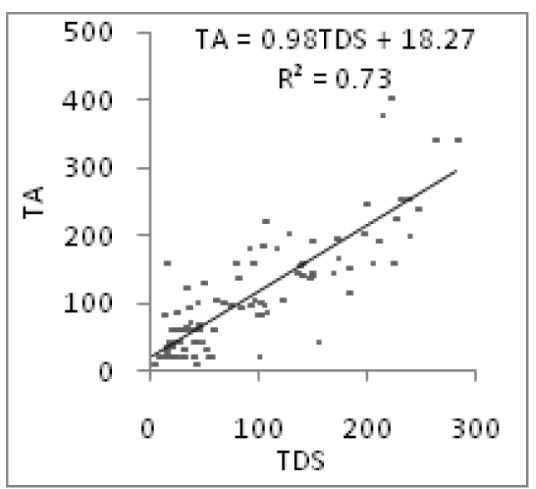

Figure 6. Correlation between TA and TDS

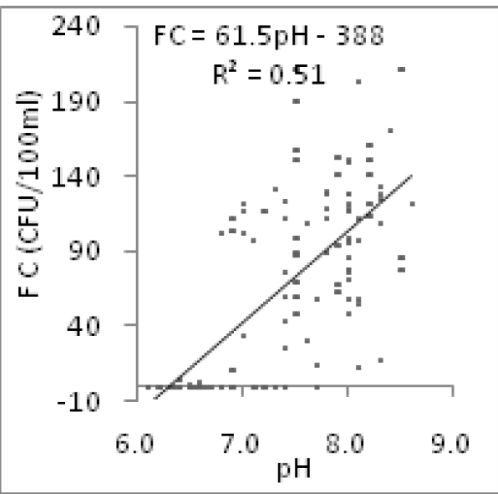

Figure 4. Correlation between FC and $\mathrm{pH}$

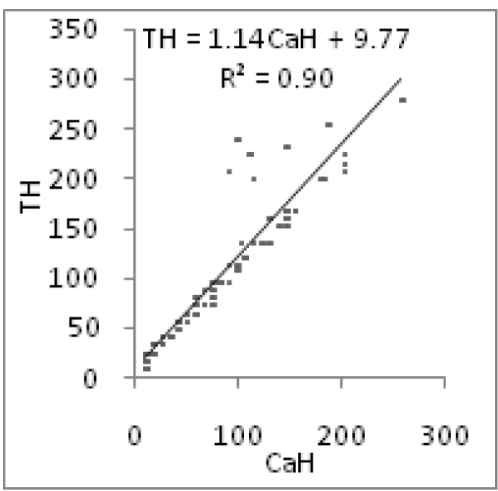

Figure 7. Correlation between $\mathrm{TH}$ and $\mathrm{CaH}$ 


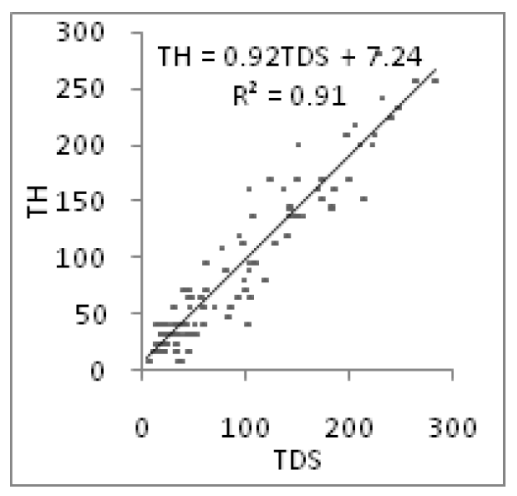

Figure 8. Correlation between TH and TDS

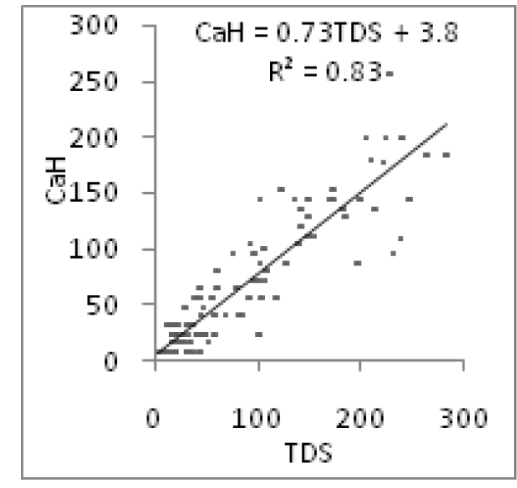

Figure 9. Correlation between $\mathrm{CaH}$ and TDS

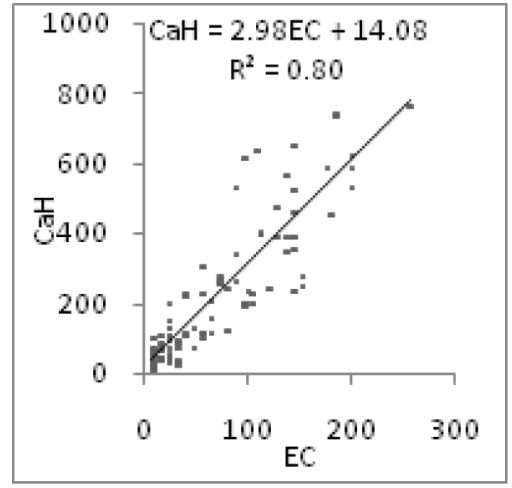

Figure 10.Correlation between $\mathrm{CaH}$ and EC contamination through masonry building, prohibition of latrine construction within the periphery of the ground water sources and uphill of the spring sources, removal of iron and manganese by aeration settling and sand filtrations and adoption of appropriate water treatment at household level such as boiling, SODIS, filtration are highly recommended.

Bishnu Pandey, took his MSc degree in Environmental Science from Tribhuvan University, Nepal. He is a Lecturer at Department of Environmental Science, Amrit Campus, Kathmandu. He also works as a research assistant at ENPHO (Environment and Public Health Organization). He has attended various scientific conferences, seminars and training. His area of interest includes Environmental Chemistry and Environmental Geology.

Corresponding address, Email: globalwarming2012@ gmail.com.

Suman Shakya, holds PhD degree in Applied Natural Sciences from the Department of Hydrobiology, University of Agricultural Sciences, Vienna, Austria. Dr. Shakya is Executive Director at the Environment and Public Health Organization (ENPHO, a Nepalese NGO), and has attended various scientific conferences, seminars, and training and has published scientific papers in various journals.

\section{References}

APHA (American Public Health Association), 1995, Standard Methods for the Examination of Water and Waste Water (19th ed.), Washington, DC: APHA.

ENPHO (Environment and Public Health Organization), 2001, Drinking Water Quality and Sanitation Situation in the UNICEF's project area: Kavre, Parsa and Chitwan, Nepal, Kathmandu: ENPHO.

Khadka, M.S., 1993, The groundwater quality situation in alluvial aquifers of the Kathmandu Valley, Nepal, AGSO Journal of Australian Geology and Geophysics 14:207-211.
Merz, J., G. Nakarmi, S.K. Shrestha, B.M. Dahal, B.S. Dongol, M. Schaffner, S. Shakya, S. Sharma, and R. Weingartner, 2004, Public water sources in rural catchments of Nepal's middle mountains-issues and constraints, Environmental Management, 34(1):2637.

MPPW (Ministry of Physical Planning and Works), 2062 BS (2005 AD), National Drinking Water Standards, 2062 BS (2005/06 AD) and National Drinking Water Quality Standard Implementation Guideline, 2062 year: 2063(BS) (2006/o7 AD), Kathmandu: Government of Nepal, MPPW.

Rafferty, K., 1999, Scaling in geothermal heat pump systems, Idaho Falls, ID (USA), U.S. Department of Energy, Idaho Operations Office. URL: geoheat.oit.edu/ otl/scaleghp.pdf.

UN-Water, 2008, Tackling a Global Crisis: UN International Year of Sanitation, New York: Division for Sustainable Development, Department of Economic and Social Affairs, UN-Water. URL: esa.un.org/iys/ health.html.

Warner N.R., J. Levy, K. Harpp and F. Farruggia, 2008, Drinking water quality in Nepal's Kathmandu Valley: A survey and assessment of selected controlling site characteristics, Hydrogeology Journal 16:321-334.

WaterAid, 2006/2007, Annual Report 2006/07, London, UK: WaterAid. URL: wateraid.org/documents/ plugin_documents/annual_report.iii.pdf.

WHO (World Health Organization) and UNICEF (United Nations Childern's Fund), 2004, Meeting the MDG drinking water and sanitation target: A midterm assessment of progress, Geneva and New York: WHO and UNICEF. URL: who.int/water_sanitation_ health/monitoring/jmpo4.pdf. 